\title{
INTEGRATED MANAGEMENT PROGRAM AND THE ECONOMIC EFFECTS OF (APHIS CRACCIVORA KOCH) (HOMOPTERA: APHIDIDAE) INFESTING GREEN BEANS, PHASEOLUS VULGARIS
} L. AT MENOUFIA GOVERNORATE, EGYPT

\author{
M.O. Kolaib, A.A. El-Dash, B.M. El-Defrawy and M. Hossiny \\ Economic Entomology \& Agricultural Zoology Dept., Fac. of Agric., \\ Menoufia University, Egypt \\ Received: Mar. 6, 2018 \\ Accepted: Apr. 18, 2018
}

\begin{abstract}
The integrated control of aphid achieved highly significance differences, so that the aphid population in IPM field formed $18.4 \%$ comparing with the total average in the farmer field. The green beans yield gained net return about 10000 Egyptian pounds / feddan as a result to apply the IPM program.
\end{abstract}

Key words: IPM program, Aphis craccivora, Green beans plant, Phaseolus vulgaris $L$.

\section{INTRODUCTION}

The green beans, Phaseolus vulgaris

$L$. is considered one of very important vegetable crops in different countries all over the world. In Egypt the cultivated area reach about 53000 feddan give dry and snap bean yield about 3-5 Tons /feddan, (FAO, 2017). The green beans is considered one of the most important source of human dietary protein and it comes in the second order as export crop after potato crop. Damage caused by the insect pests is considered the limit factor of beans production. The sab suckers such as aphids cause inflict significant damage, aphids are important pests of most cultivated crops worldwide (Abate and Ampofo, 1996 and Boivin et al., 2012, May-Guri et al., 2011). Biological control provided by natural enemies play an important role in integrated pest management. Generalist insect predators provide an important biological service in the regulation of agriculture insect pests (Ouyang Fang, 2013, Trottin-Caudal, et al., 2012). The present work is focusing on the important insect pest (Aphis craccivora) infesting the green beans specially the integrated pest management and the comparison between the yield and the cost of production.

\section{MATERIALS AND METHODS}

To apply the IPM program one feddan of lands was planted with Green bean (Bronco cultivar) in Ashmoon region, Menoufia Governorate, during February, 2017. Half area (12 kerats) was divided and applied to serve the farmer treatment as follow:

1- Lambada $5 \%$ at the rate $250 \mathrm{ml} / 200$ liter water.

2- Mosblan 20 (Asetampraid) at the rate of $50 \mathrm{~g} /$ feddan.

3- Clorburefios $48 \%$ at the rate of $500 \mathrm{ml}$ /200 liter water.

The second half of area (12 kerats) was served to apply the suggested IPM program.

During May, 10 and 25, 2017 samples of $\mathbf{1 0}$ leaves and $\mathbf{1 0}$ fruit were collected and transferred to the laboratory of the Department of Economic Entomology and Agricultural Zoology of the Faculty of Agriculture, Menoufia University, Shebin Elkom, Egypt.

The predator was obtained from the laboratory of biological control - rearing 
predators unit at Faculty of Agriculture, Cairo University, Egypt, under the supervision of Prof. Dr. Ashraf Elarnaouty.

The treatments of the IPM program where different agents were applied are listed in Table (1).

\section{RESULTS AND DISCUSSION}

To indicate the integrated control of green beans aphid, Aphis craccivora, Koch, Data obtained of comparison between the average numbers of aphid in both IPM field and farmer field (Fig. 1 \& 2) revealed that the mean numbers of aphid in farmer field showed three picks of abundance of 25,35 and 40 individual during mid-Marsh, April, 8 and April, 29, 2017, respectively. While the mean numbers of aphids recorded $0.2,0.7$ and 0.3 insects in IPM field in the same period and these values were the lowest abundance. Generally, the total mean numbers of farmer and IPM field were 17.38 and 2.86 individuals /leaf, respectively. The average percentage of IPM field during the period of experiment recorded $16.5 \%$ of aphid comparing with total average of aphid in the farmer field. Statistical analysis were applied by using T. test showed highly significant differences between the population density in both field of IPM program and the farmer, this results confirm the role of integrated control in Aphis craccivora control.

Respecting, the economic effects of integrated control program has achieved a great impact in the production of green beans, since the cultivated feddan by green beans give about half ton more than farmer field and the net return reached about 10000 Egyptian pound per feddan (Tables 2 and 3 ).

Table (1): Insecticides used to control Aphis cracovora Koch in the IPM program

\begin{tabular}{|c|c|c|c|}
\hline $\begin{array}{c}\text { Treatment } \\
\text { date }\end{array}$ & Trade name & Active ingredient & Rate of application \\
\hline $25 / 02 / 2017$ & Actara & Thiamethoxam25\% WG & $20 \mathrm{~g} / 100$ liter water \\
\hline $10 / 03 / 2017$ & Aphid lion & Chrysoperla carnea & 360 larvae/ feddan \\
\hline $01 / 04 / 2017$ & Asitaplan & Acetamiprid $20 \% \mathrm{SP}$ & $50 \mathrm{~g} /$ feddan \\
\hline $16 / 04 / 2017$ & Danksweet & Dimethoate $40 \% \mathrm{EC}$ & $30 \mathrm{~cm} / 100$ liter water \\
\hline $01 / 05 / 2017$ & Vertimc & Abamectin $1.8 \% \mathrm{EC}$ & $40 \mathrm{~cm} / 100$ liter water \\
\hline $10 / 05 / 2017$ & Biovar & Beauveria bassiana & $\begin{array}{r}10 \%\left(32 \times 10^{6}\right) \text { conidia/g } \\
200 \mathrm{~g} / \text { feddan }\end{array}$ \\
\hline $25 / 05 / 2017$ & Dipel $2 X$ & Bacillus thuringiensis & $\begin{array}{r}6.4 \%\left(32 \times 10^{3}\right) \text { lu/mg } \\
200 \mathrm{~g} / \text { feddan }\end{array}$ \\
\hline
\end{tabular}




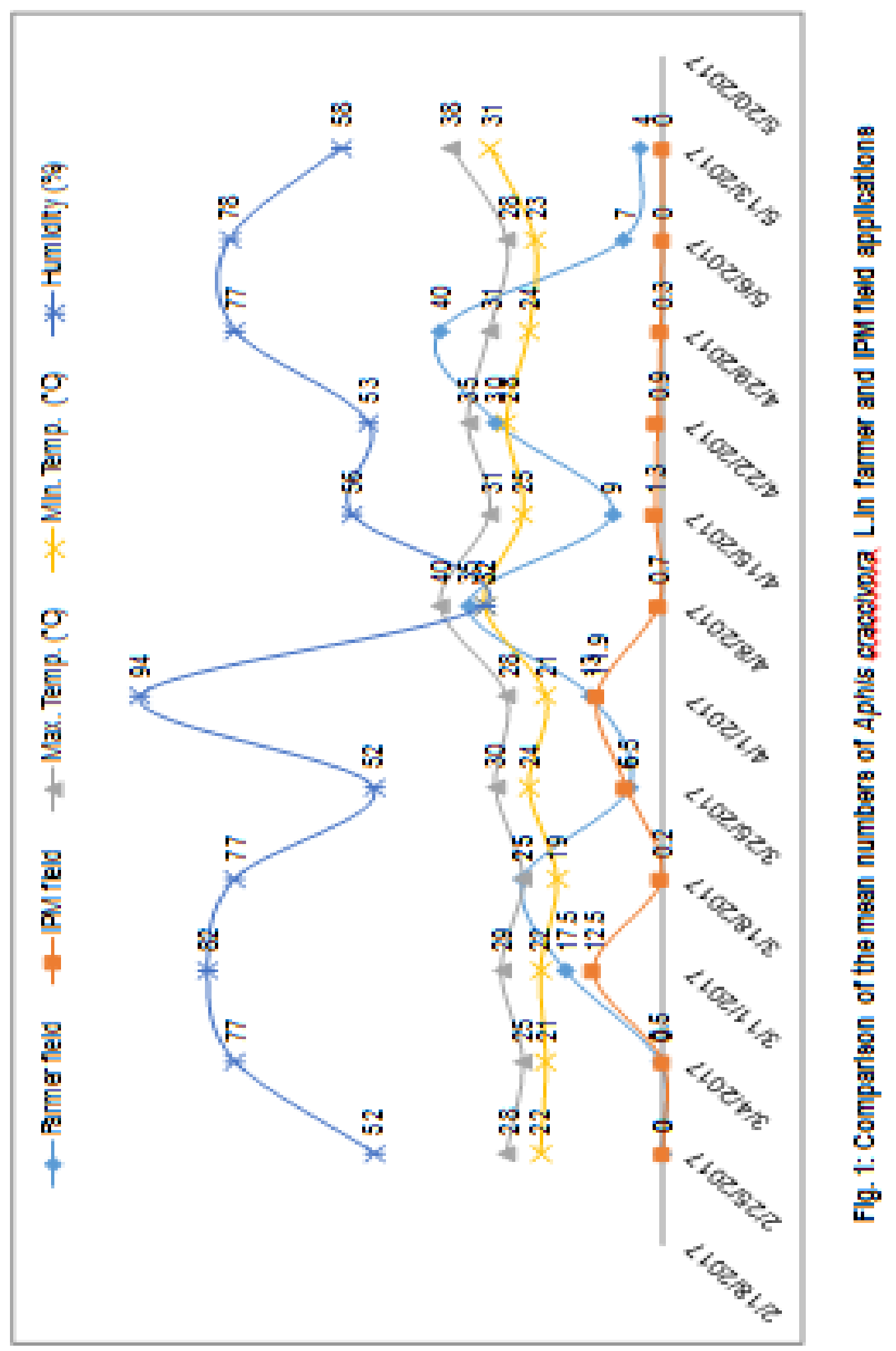




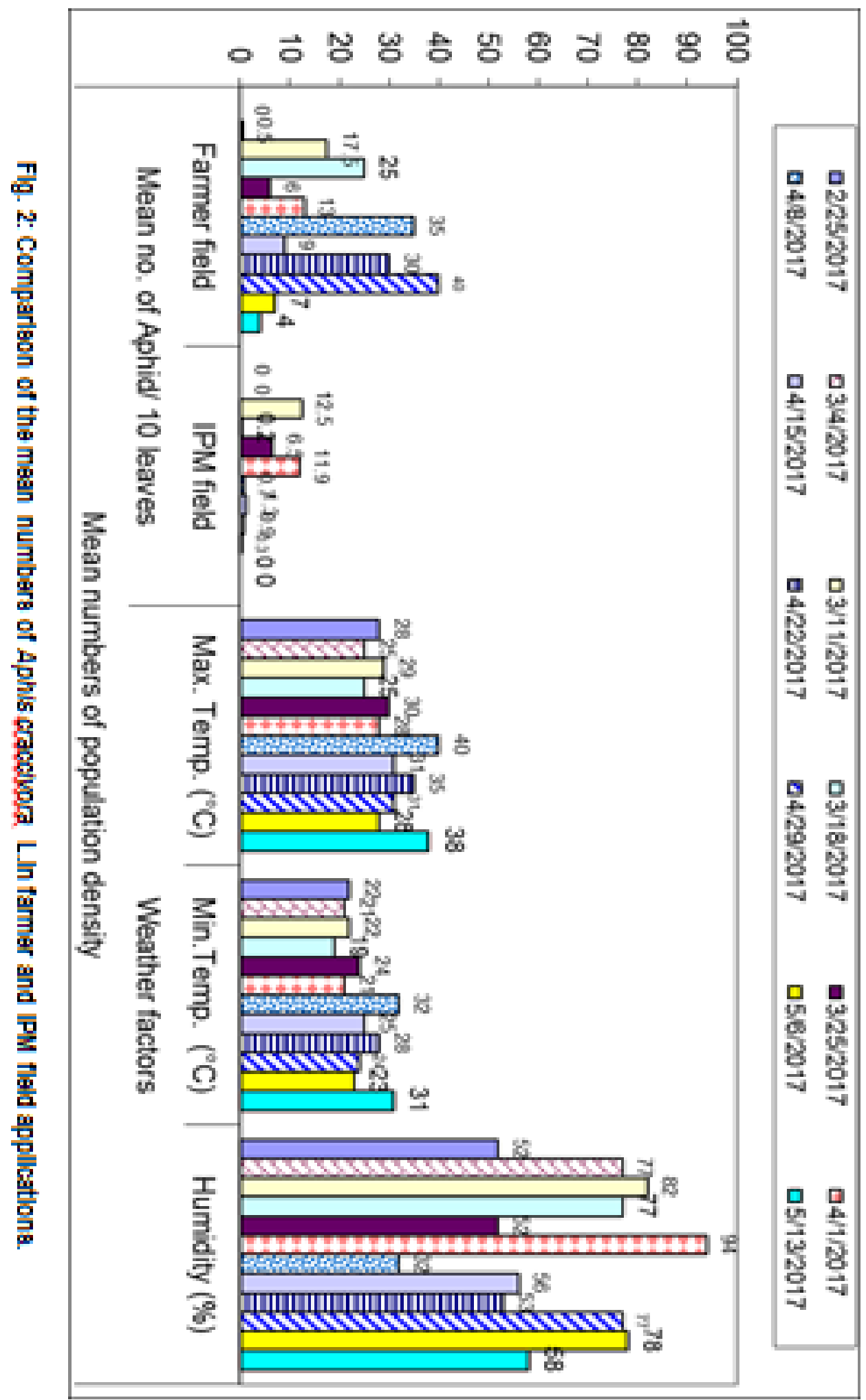


Table (2): Comparison between Yield and cost of production of both IPM and farmer field during the summer season of 2017

\begin{tabular}{|c|c|c|c|c|c|c|}
\hline $\begin{array}{c}\text { Yield } \\
\text { weight } \\
\mathbf{( k g} / / \\
\text { feddan }\end{array}$ & $\begin{array}{c}\text { Yield } \\
\text { return } \\
(\text { LE }) / \\
\text { feddan }\end{array}$ & $\begin{array}{c}\text { Cost of } \\
\text { Insecticidal } \\
\text { Treatments } \\
\text { (LE)/ feddan }\end{array}$ & $\begin{array}{c}\text { Cost of } \\
\text { Predacious } \\
\text { Release } \\
\text { Treatments/ } \\
\text { feddan }\end{array}$ & $\begin{array}{c}\text { Cost of } \\
\text { agriculture } \\
\text { Practices (LE) / } \\
\text { feddan }\end{array}$ & $\begin{array}{c}\text { Cost of net } \\
\text { applications } \\
\text { /feddan }\end{array}$ & $\begin{array}{c}\text { Net return } \\
\text { (LE) / } \\
\text { feddan }\end{array}$ \\
\hline 1560 & 24960 & 400 & 300 & 5500 & 6200 & 18760 \\
\hline \multicolumn{7}{|c|}{ IPM } \\
\hline 1080 & 15120 & 800 & 0 & 5500 & 6300 & 8820 \\
\hline
\end{tabular}

Table (3): Economic evaluation of IPM and farmer field applications

\begin{tabular}{|l|c|c|}
\hline \multicolumn{1}{|c|}{ Economic Item } & Farmer field & IPM field \\
\hline Total of costs & 6300 & 6200 \\
\hline Yield/ Ton & 1.080 & 1.560 \\
\hline Price /kg & 14 & 16 \\
\hline Total price / feddan & 15120 & 24960 \\
\hline Average net return/feddan & 8820 & 18760 \\
\hline
\end{tabular}

\section{REFERENCES}

Abate T. and J.K.O. Ampofo (1996). Insect pests of beans in Africa: Their ecology and Management Annu. Rev. Entomol. 41: 43-73.

Boivin, G., T.S. Hance and J. Brodeur (2012). Aphid parasitoids in biological control. Canadian Journal of Plant Science. 92(1):1-12.

May-Guri, S., I. Godonou, S. Leclercq, G. T. Yoto and B. James (2011). Assessment of aphid ecology in vegetable systems and potential for biological control agents. Acta Horticulturae. (911):227-230.
Ouyang Fang, Men Xing Yuan, Yang Bing, Su JianWei, Zhang Yong Sheng, Zhao Zihua and Ge Feng (2013). Maize benefits the predatory beetle, Propylea japonica (Thunberg), to provide potential to enhance biological control for aphids in cotton. PLOS ONE. 7(9): e44379. 31.

Trottin-Caudal, Y., V. Baffert and J.M. Leyre (2012). Experimental studies of the biological control of aphids in protected strawberry crops in France. IOBC/WPRS Bulletin. 80:159-164. 
برنامج للمكافحة المتكاملة لحشرة المن Aphis craccivora التى تصيب نباتات الفاصوليا تحت الظروف الحقلية فى محافظة المنوفية

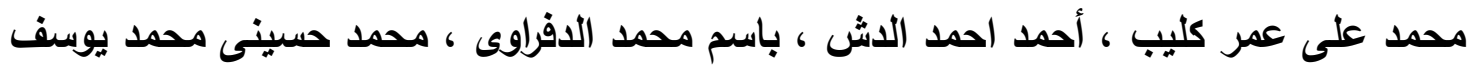

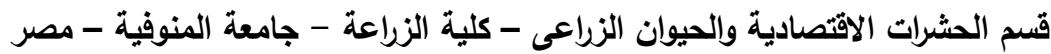

الملخص العربى

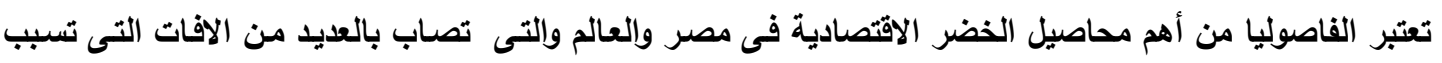

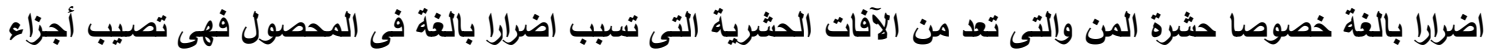

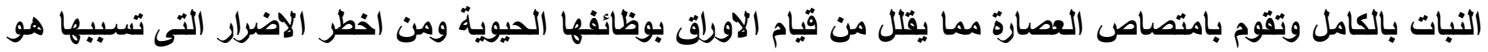

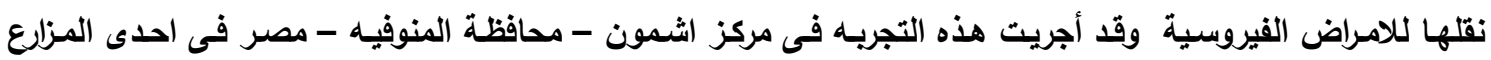

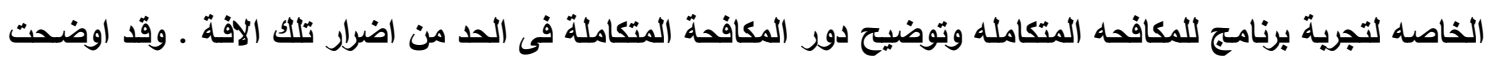

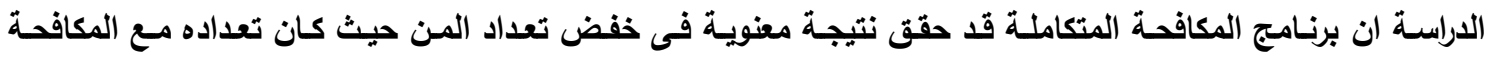

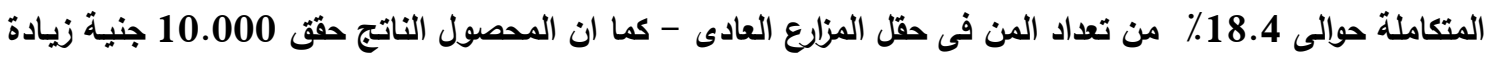

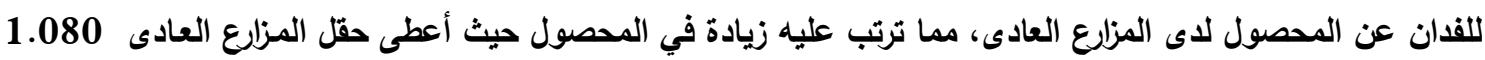

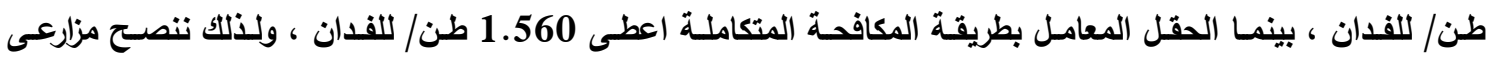

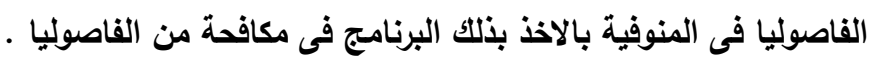


Integrated management program and the economic effects of (Aphis ............. 